\title{
BECOMING INDIANS: CERVANTES AND GARCÍA LORCA
}

SUBHAS YADAV

University of Hyderabad, India subhas.yadav@gmail.com

Received: 28-09-2018

Accepted: 03-01-2019

In the year 1831, during an auction of the previously owned books by Sir William Jones, one of the greatest linguists, famed orientalist and the founder of the Asiatic Society in Calcutta in 1784, the Antwerp version (Spanish) of Don Quixote in two volumes published in 1719 along with Viaje al Parnaso, Persiles y Sigismunda and La Galatea published in Madrid 1784 were also listed for sale. ${ }^{1}$ One of the first generation Indian Hispanic studies scholars, Shyama Prasad Ganguly also sustains the idea that the first copy of Don Quixote arrives in India with Sir William Jones. Indeed he might have brought it himself. In a letter written to Spanish jurist, writer and philologist Francisco Perez Bayer on 4 Oct, 1774, Jones thanks him for giving him the Spanish translation of Sallust done by El Infante Gabriel de Borbon and acknowledged he had read the humorous stories of Cervantes, along with Poemas Heroicas de Don Alonso y Odas de Garcilaso (Lord Teignmouth, 1806: 129). R. D. Waddilove, one of their friends, happens to hand over Sallust's translation to Sir William Jones. However, the English version of Don Quixote must have reached India at a later date. It would have become the source text for its first Bengali translation in the year 1887 entitled Adbhut Digvijay, by Bipin Behari Chackrabarti. It is a translation of 27 chapters of Don Quixote from English to his mother tongue Bengali, edited by S. P. Ganguly in 2006.

\footnotetext{
1 The Catalogue titled, "Catalogue of the library of ... sir William Jones ... which will be sold by auction, Volume 2 (1831) shows its source as Oxford University, and digitalised on 27 Jan 2009, is available on google books. Sir William might have brought these books with him to India. However, since the advent of the Spanish language in India begins later on, the translation of Cervantes must have taken place once the English copy of Quixote reached British readers. However, there is uncertainty about exactly when Don Quixote was brought to India.
} 
A noted Hindi literary critic and academic, Manager Pandey, considers Don Quixote a creation of a mature mind and mentions its first ever translation in India around the year 1870, done in Urdu by Ratan Nath Sarsar, a renowned Urdu novelist of his time (Pandey, 2013: 68). This would certainly contest the idea of the Bangla version Adbhut Digvijay (1887) being the first ever translation of Don Quixote in India. Ratan Nath Sarsar also gave a new name to Quixote as Khudai Faujdar. His own earlier and the most renowned work Fasana-e-Azad (1880) was influenced by Quixote, and later on translated into Hindi by Premchand.

Premchand (1880-1936) is perhaps the most renowned writer in the Hindi language to date or in other words can be called the Cervantes of Hindi literature. He translated Sarsar's work Fasana-e-Azad into Hindi as Azad Katha in 1925. However, the well-known translation of Don Quixote into Hindi was carried out by Chhavinath Pandey and published by the national academy of letters (Sahitya Academy) in 1964 which is also the most circulated and widely read. This version also became the source text for its Gujarati rendition in the year 2005 .

Apart from the various translations and adaptions of Quixote into Hindi literary sphere, it has wide impact on Tamil, Telugu, Oriya, Malayalam, Marathi and other regional literatures. One of the interesting features about Don Quixote is that it was translated into different forms for children and for adults. The same quixotic adventure appears as a mature tale for adults and the fun tale for children. Perhaps that is the reason we have Dan Kriksat in 1912 (translator unknown), another in 1931 with the title Don Kusti translated by Jamini Kant Som, Vichitra Vir by Jagannath Prasad Chaturvedi in 1926 and Tismar Khan in 1958.

One of most interesting adaptations of Don Quixote is certainly the Kathakali theatre adaptation by the Margi group from Kerala. The vice president of the group P. Venugopalan wrote the adaption, in which 78 year-old Nelliyod Vasudevan Namboothiri played the role of Quijano. It is a collaboration between the modern Spanish theatre professionals and the traditional Kathakali theatre artists. The team had its performance in their home theatre on July 3, 2016 and visited Spain to participate in the International Classical Theatre Festival of Almagro on July 22, 2016 and performed at five more venues too. ${ }^{2}$ The Indian media's

\footnotetext{
${ }^{2}$ Almost all major newspapers in India such as The Hindu, Times of India, The Statesman, Deccan Chronicle, India Today, Indian Express, The Hindustan Times etc and news portal such as The Quint, DNA etc. published the news of Quixote performed in Kathakali form. The Spanish press has equally given due attention to the performance of the Margi Group in the Almagro theatre festival and their collaboration with their Spanish counterparts.
} 
coverage of the adaptation of Quixote to Kathakali was also favourable. The novel, however, has not yet taken to the screen of mega cine industry in India but certainly it has tasted the music, colours, emotions and the philosophy of Indian culture through this performance. The veteran Bollywood actor Dilip Tahil has already produced a musical on Don Quixote and staged it in different parts of the country including New Delhi and Mumbai.

The case of Federico García Lorca is even more interesting, which has made his reach even deeper in India. His poems and plays received a warm reception along with Neruda's poetry because of its anti-fascist and emancipatory stand. S. P. Ganguly notes that during the anti-imperialist struggle in India, these authors rightly found their way to the Indian literary scene (Ganguly, 2005a). One of my colleagues, a drama teacher at an international school in Hyderabad, a southern Indian city, Venkat Ramanna mentioned that he had won a national prize with a theatre work called House of Bernarda Alba but he did not know if it was a Spanish play. He thought, like everyone else, that it was an English play. Thereafter, I realised that he was talking about La casa de Bernarda Alba by García Lorca. He acknowledged having directed Bodas de sangre, translated into English as well, without having a sound understanding of Spanish literature. Moreover, another theatre director in Hyderabad, Vinay Varma has directed The House of Bernarda Alba on many occasions since 2012. This famous work by García Lorca was translated by Raghupati Sahay during the 1980s into Urdu, a widely spoken language in the Indian subcontinent.

During the International Theatre Festival in London in 1993, a Punjabi woman director Neelam Chowdhry presented Yerma by García Lorca, which El Pais, a Spanish daily, mentioned in its article dated $29^{\text {th }}$ June, 1993, as "Yerma is Now an Indian Woman". 3 Director Choudhry, herself from rural India, had an arranged marriage and finds the social reality of Yerma similar to her own and underlines:

Federico García Lorca is not a Spanish author. His passion, music, rhythm are part of Indian culture. Yerma can be a story of any Indian woman today. She is expected to marry as a virgin and to produce a male child else the husband would search for another woman (Chowdhary: 1993)

The Andalusian society in which Lorca lived could be similar to contemporary Indian society, where honour of the house, religiosity, virginity, moral codes and the authority of family heads are of utmost significance. Monica de la Fuente, a flamenco and

\footnotetext{
3 For details see the article titled, "Yerma es una mujer india" published in El Pais on its website https:/elpais.com/diario/1993/06/29/ultima/741304801_850215.html
} 
Bharatanatyam dancer presented Rasa y duende, Paisaje interior del cante jondo, a dance and musical show based on Lorca's poem Cante Jondo during the Jaipur Literary Festival in India on 22 $2^{\text {nd }}$ January, 2015, accompanied by Shabana Azmi, a veteran Bollywood actress, daughter of poet Kaifi Azmi and wife of Javed Akhtar, a lyricist. ${ }^{4}$ Her daughter Zoya Akhtar shot the hit Bollywood movie Zindagi Na Milegi Dubara (dubbed in Spanish as 'Solo se vive una vez') in Spain, featuring la Tomatina. Subsequently, according to the director of Casa India in Valladolid Indian tourism grew by $25 \%$ after that movie. She has been presenting her show all over Spain and below is an online invitation of the show on the website of the Museo de Tenerife:

Festival MusaIndia. Ciclo de música y artes escénicas. Compañia Mónica de la Fuente presenta «Rasa Duende» Lorca, flamenco y las artes escénicas de la India

- Lugar: Museo de la Naturaleza y el Hombre (Tenerife)

- Día: 1 de septiembre de 2017

- Hora: 21:30 h

- Entrada gratuita hasta completar aforo ${ }^{5}$

Moreover, Yerma is adapted by the veteran dramatist Mahesh Dattani and Neha Sharma, entitled Maati. They set the story in Haryana, a state known for female foeticide and imbalanced male-female ratio. Dattani has "physicalised" the contradictions of Lorca's heroine by giving Maati three identities - male, female and transgender. ${ }^{6}$ Following performances in Bengaluru and Pune, Maati was staged in Mumbai at G5A on April 6, 2018 at the Experimental Theatre, NCPA, on April 18 and at the Mumbai Marathi Sahitya Sangh on May 4.

García Lorca's works not only find their reception among Indians in India, but among the non-resident Indians overseas as well, especially the UK diaspora. Yerma was

\footnotetext{
4 The Jaipur literary festival is the most prestigious literary event in India. For details see https://www.cyclinjaipur.com/single-post/2015/01/20/Jaipur-Literature-Festival-2015-Live-music-sessionsprogram-

5 The post gives detail about the program and about Monica de la Fuente as well. http://www.museosdetenerife.org/mnh-museo-de-la-naturaleza-y-el-hombre/evento/4743

${ }^{6}$ An article published about their performance in the renowned magazine India Today, which attests the fame of the theatre group and the play as well. https://www.indiatoday.in/magazine/leisure/story/20180402-theatremahesh-dattani-maati-drama-school-mumbai-1196393-2018-03-23
} 
adapted back in 1995 by a London-based theatre company Tamasha (www.tamasha.org.uk), as $A$ Yearning by Ruth Carter in which Amar

a bride from India, yearns for a child but her husband Jaz is too preoccupied with his Birmingham minicab firm to see her loneliness. Faced with Amar's failure to conceive, the community that was once nurturing becomes increasingly stifling. A transposition of Lorca's classic to Britain's Punjabi community, A Yearning addresses the plight of a woman married into a society where her real worth is measured by her ability to have children. The play had among its actors Zohra Segal, a veteran Indian theatre and cinema artist. (Tamasha: n.d.)

It is also worth mentioning that this play has won the CRE, Race in the Media Award and is described by the Birmingham Weekly Observer as "An intelligent, thought-provoking production, opening a surprisingly accurate window into the aims and aspirations of the Punjabi community in our own city." The Spanish play being considered as an accurate window into the realities of Punjabi culture, signals towards a transcreation of the play into the Indian milieu.

Moving to the southern part of India, a national letters awardee playwright, poet and filmmaker Chandrashekhara Kambara made his mark in film-making by adopting La Casa de Bernarda Alba on screen as Kadu Kuduree in the year 1978 (Kasbekar, 2006: 73). He has recently been elected as the president of the Sahitya Academy, the national letters academy of India. Kambara mentions that he was impressed by the Spanish playwright Federico García Lorca's works. In an article published in the Times of India dated 29th March, 2013, he further writes that “Though I've read Shakespeare's Othello, Macbeth and King Lear, Lorca's play The House of Bernarda Alba impressed me a lot. He is close to our theatre. We always tell a story in our plays. Though Lorca wrote very few short plays, he told stories through them". ${ }^{7}$ Such close relatedness with Spanish culture makes Lorca's translation, adaptation, transcreation or localization a receptive task. Unlike other western literary works where such cultural parallels are not drawn easily, its receptions are not that easy and not every translator or littérateur accepts the task. Once again Federico García Lorca's "Blood Wedding” was reproduced in an Indian setting in a play designed and directed by Neelam Mansingh Chowdhry and performed by the National School of Drama Repertory Company in the last week of November 2010. P Anima writes, "The earthiness of Lorca's text, the link of the Spaniards to their soil, is easily translated into a Punjabi-Rajasthani setting."8

\footnotetext{
${ }^{7}$ For details see https:/timesofindia.indiatimes.com/city/bengaluru/Forest-is-narrator-in-Kambars-newplay/articleshow/19268442.cms

${ }^{8}$ For details see the complete article https:/www.thehindu.com/todays-paper/tp-features/tp-fridayreview/Theagony-of-loss/article15715872.ece
} 
However, two cases of Lorca's adaptations are milestones in the Indian literary history. The House of Bernarda Alba was adapted and translated by the versatile Hindi poet and writer Dr Raghuvir Sahay (1929-1990) as Birjis Qadar Ka Kunba, and produced in 1980 by Amal Allana who later became a prominent Indian theatre director; she is now the chairperson of the National School of Drama. Raghuvir Sahay's translation of The House of Bernarda Alba not only created a wave of theatrical adaptation of Lorca's play in India but also in the neighbouring country Pakistan, and furthermore taken abroad by non-resident Indians wherever they migrated out of the subcontinent. To date, his version Birjis Qadar ka Kunba is performed by many theatre groups with contextual adjustments of the story.

The other event was the making of a film, Rukmavati ki Haveli - a cinematic rendition of La Casa de Bernarda Alba into Hindi. Govind Nihalani wrote his own screenplay and in 1991 made it into a Hindi feature film, Rukmavati ki Haveli, set in a Rajasthan village, by casting actors like Ila Arun and Pallavi Joshi. Amparo Rodrigo Mateu has interviewed Govind Nihlani for Revista Foto Cinema, which gives valuable inputs on its rendition and reception in India. Govind Nihlani (born in Karachi 1940) like many Bollywood directors and artists hails from the cultural hub of the then undivided India, Karachi, now in Pakistan. His vision must be larger than what the Indian scenario is just now. Soaked into the fusion of Islamic, Sikh and Hindu culture, and after coming to Mumbai, perhaps the most westernised city of what was then India must have enabled him to fuse a distant Western Andalusian story into Indian reality. Answering to the very first question by Amparo Rodrigo, "Why did you choose Lorca and, among all his works, what attracted you to La casa de Bernarda Alba?"9 Nihlani recalls

When I read The House of Bernarda Alba again, the same image of those women coming down that fort kept haunting me, so I decided to take that forward and I decided to place it in Rajasthan because Rajasthan is very close to the original play, since it is a very feudal culture, particularly in olden times. I thought that these seven women; one mother, one maid and the five girls in an old haveli would be wonderful. So I decided to go for this play and make it into a film. I was very thrilled. I recreated the entire environment of a Rajasthani haveli and I gave these women the same color, the same kind of dress which I had seen. In my film you see the women also dressed in deep red, maroon and black and, of course, there is no jewellery because the ladies are widows. Apart from that I liked the theme as well. I was able to combine my aesthetic sensibility, my cinematic sensibility and my social and political concerns. And I was lucky to get very good actresses at that time. That is how you make a film. (Rodrigo: 2016)

\footnotetext{
${ }^{9}$ Amparo Rodrigues Mateu, perhaps during her stay in Mumbai as a Spanish teacher at the University of Mumbai interviews Govind Nihlani. Nihlani is no doubt one of the most renowned art film directors in Indian cinema. A six times winner of National Film Awards, he has also adopted to the screen Hazaar Chaurasi ki Maa, a national award-winning novel by Mahasweta Devi on the mother of a Naxalite youth.
} 
It is interesting to note how Govind Nihlani easily renders the southern Spanish literary reality of Lorca in the western Rajasthan's feudal settings. He considers that the Rajasthani reality is closer to the original play, and stresses that he used the same colour of clothes except the jewellery. These amenable parallelisms have also been noted in the theatrical adaptations of the London-based Tamasha theatre group, Sonal Mansingh Choudhary, Mahesh Dattani or the Amina Khayyam Dance Company. Answering to another question: Do you have any future similar adaptations in mind? He states:

I am a great fan of Lorca and one of my ambitions is to do a trilogy. Yerma (Federico García Lorca, 1934) is a very popular play here in India, particularly in drama schools. I want to adapt Yerma and also Blood Wedding (Bodas de sangre, Federico García Lorca, 1931) into cinema, with Indian characters and Indian dresses. If I get some funding, that is what I would like to do. (Rodrigo: 2016)

When Nihlani states that Yerma is a very popular play in India, it does not surprise me to recall my colleagues winning a national prize with their theatrical adaptation of Bodas de Sangre in a theatre competition. In fact Lorca has already been born in its Indian avatar, and enriching the literary and cultural spheres for many decades now.

Indians or the people from the entire Indian subcontinent residing in the West find Lorca's plays and other literary works closer to their native culture and tend to take a literary refuge in them, which does not easily happen with other western literary works. It is also underlined by the Kannada playwright, cinema director and current director of Sahitya Academy, Chandrasakher Kambhar. The UK-based Amina Khayyam Dance Company, which fuses Indian classical instruments such as Tabla with western instruments, does the same with the theme by their Kathak rendition, a mix of dance and theatre of Lorca's tragic play Yerma. The opinions of various newspapers and magazines offer a better understanding of this adaptation. ${ }^{10}$

"This isn't dance narrative as we know it but something that burrows much deeper into the emotional roots of Lorca's play, finding a poetry of its own" $-4^{* * * *} /$ FestMag ${ }^{11}$

\footnotetext{
${ }^{10}$ The performance of Yerma on 6 April, 2016 by the Amina Khayyam Dance Company advertised in The Courtyard Centre for the Arts in Herefordshire mentions details on its websites. The citations of opinions from magazines and newspapers are also taken from there. The advertisement reads as following "Amina Khayyam Dance Company bring the anguishing story of Yerma to The Courtyard, in a re-imagining of Federico García Lorca's savage yet lyrical play - Wednesday 6 April, 7.30pm."

${ }^{11}$ These are star ratings of the play given by the magazines, in which 5 star is the highest and 1 star stands for the lowest rating.
} 
"Powerful, poignant kathak dance...sharply stylized.. dramatically alert, thematically rich and ultimately moving" $-4 * * * * /$ The List

"Emotive, well-choreographed. The highlight is Yerma's expressive eyes. For a dancer to be able to tell the entirety of the narrative just through her eyes, it's astonishing" $-4 * * * * 1$

Edfest Mag

Lorca's play Yerma about a childless woman, may be set in $19^{\text {th }}$ century Spain but there are many societies in the world still living that epoch or perhaps they are still far behind it. The feudal structure of the society, and the patriarchal setting of families are not much different from what Yerma depicts. In Indian society where seeing a childless mother's face is considered a bad omen, and who is subjected to taunts in the neighbourhood and torture in the family, the reality of Yerma is not irreverent. Amina herself coming from a south Asian immigrant family in the UK recalls in an interview with www.londondance.com on 30 october, 2013:

... I grew up with stories around me from my own community where if a woman was unable to bear a child, she would automatically be considered to be at fault! The family would then force the husband to remarry so he may get a second chance to have a child...Amazing that while the play was written in 1934, it is so topical for many women around the world today in numerous different cultures who find themselves in similar situations... Today, Europe has new Yermas seething on the fringes of inner-cities, hidden behind the insularity of communities where women's issues still have a long way to go... I approach the re-telling of Yerma using the passion of Kathak. I use Abhinaya - the gestural facial expressions - as the central movement within it, but I subvert it by negating it - so that my Yerma wears a face of death - there is no prettiness, no jewels, no shine. Rural Spain of Yerma is transposed to contemporary Britain: some issues remain the same (Khayyam: 2013).

It is tragic to see that even the South Asian families domiciled in western countries have to struggle against the problems of their ancestral culture. However, their location in the western milieu connecting them through Lorca's literary works reaches towards the roots of their Indian or south Asian culture. The canalization of literary and aesthetic currents between the West and the East, and the creation of a natural fusion leads us to understand and note the phenomena of localization of Cervantes and Lorca in India. However, looking at this phenomena through the lens of reader-centric reception theory would offer us a number of answers to the question why there is such a warm reception of Cervantes and Lorca? For Don Quixote undeniably it can be the universality of its theme and storytelling, and for García Lorca it could be the oriental elements in his works.

While examining the first reception of Don Quixote in India, we come across the 
Urdu masterpiece, Fasana-e-Aazad, considered to be the reworking of dastan narrative alongside a complex engagement with Don Quixote (Peers \& Gooptu, 2012: 275). Since, the Indian readers were already familiar with the pervasive Perso-Arabic dastan ${ }^{12}$ tradition in the literary narrative world, it would have been a favourable aesthetic response for the Castilian quixotic adventures. The importance of parallelism reflects from the entry on Fasana-eAazad in the 'The Encyclopedia of Indian Literature Vol 2.' published by Sahitya Academy in 2006 which says:

Fasana-e-Aazad does not fulfil the technical requirements of a novel. It is something between a dastan and a novel...the most celebrated character of this novel is Khoji. The tale is told in 4000 long pages. Azad, a handsome youth, scholar, poet, wrestler and warrior, with modern reformist ideas, is fond of festivals, festivities, picnics, sightseeing etc. He has his Sancho Panza in Khoji, a master-creation of Sarshar. This man is conservative, clownish but very faithful and devoted to Azad. Khoji has a grotesque personality but regards himself handsome and as one who can win the hearts of young girls. In him Sarshar has created an immortal character of Urdu fiction (Datta 2006: 1265).

Aesthetic distance in this case is clearly very minimal, hence, it paved an easy way for the quixotic tale to permeate into the Indian literary sphere, not only in the written tradition but also in the oral tradition. ${ }^{13}$ Sisir Kumar Das in his encyclopaedic study on Indian literature, while talking about the sacred text Gita, mentions that the veteran Indian historian D. D. Kosambi posed a question: "was there no Sanskrit literary work that gave form to the Indian character in the same way that Cervantes's Don Quixote set its stamp upon the Spanish literati" and finds that it is Gita (Das 1995: 49). From comparison between Don Quixote and Gita, to multitude of translations, theatrical and musical adaptations, Don Quixote certainly leaves an indelible mark on the Indian literary sphere.

When analysing Lorca's reception, one must explore his Indian connection. It is known that he owned a copy of La filosofia esotérica de la India (1914) by Brahmacharin Bodhabhikshu (J. C. Chatterji), and was introduced to Indian philosophy by his medical doctor friend, Jose Murciano, a believer in parapsychology (Gibson 2016). Besides, Lorca’s

\footnotetext{
12 Dāstān means "story," a popular narrative genre whose root goes back to medieval Iran. These were tales of heroic romance and adventure stories about gallant princes and their encounters with evil kings, enemy champions, demons, magicians, jinns, divine emissaries, tricky secret agents called iayyārs, and beautiful princesses who might be human or of the Parī ("fairy") race. For details see: http://www.columbia.edu/itc/mealac/pritchett/00litlinks/hamzah/index.ht

${ }^{13}$ S P Ganguly in his article "Don Quijote bajo el cielo indio" talks about both types of reception including eight translations in different languages (Hindi, Urdu, Bangla, Marathi, Telegu, Tamil, Oriya, Malayalam, Kannada, and Gujarati) and notes that none of them were actually translated from the original.
} 
unedited poem Budha (1918) offers enough base to understand his oriental connections, which mature as time passes, and he does produce more bridging works such as Divan de tamarit written in 1934, and posthumously published in 1940 by Editorial Losada. His Poemas de cante jondo further attest his intra-literary connection with India. The poem Candil, from Cante Jondo dedicated to Regina Sainz de la Maza, compares through a simile, the flame of an oil lamp with an Indian fakir. Lorca made connections among cante jondo, a mystical Orient and Indian culture (Bonaddio 2010: 72).

¡Oh, qué grave medita la llama del candil!

Como un faquir indio mira su entraña de oro y se eclipsa soñando atmósferas sin viento...

Don Quixote's connections might have been easily established due to the Islamic traces vitally present in Spain during the time of Cervantes, but even after five centuries this connection does not fade away, in fact it re-affirms its root through Lorca and completes a circle and offers Indian readers their own Cervantes and García Lorca.

\section{WORKS CITED}

ANIMA, P. (2010). "The Agony of Loss" The Hindu. 26 Nov. $<$ https://www.thehindu.com/todays-paper/tp-features/tp-fridayreview/The-agony-ofloss/article15715872.ece. $>$ accessed 10 September 2018.

ANON. (2017). "Flamenco con toques de la India" El Dia. 31 Aug. $<$ http://eldia.es/cultura/2017-08-31/3-Flamenco-toques-India.htm> accessed 10 September 2018

ANON. (2016). "Cervantes y Lorca, protagonistas de festival de la India en Valladolid" El Adelantado. 6 June. $<$ http://www.eladelantado.com/nacional/cervantes y lorca protagonistas del festiva 1 de_la_india_en_valladolid/> accessed 12 September 2018 
ANON. (2016). "Yerma - "Exquisite, Breathtaking, Powerful and Poignant", courtyard.org.uk, <https://www.courtyard.org.uk/yerma-exquisite-breathtakingpowerful-poignant $/>$ accessed 12 September 2018

ANON. (2013). "Interview: Amina Khayyam - on Yerma \& 'The Passion Of Kathak"” Londondance.Com. 13 oct. http://londondance.com/articles/interviews/aminakhayyam-yerma/ accessed 10 september 2018

ANON. (1831) "Catalogue of the library of Sir William Jones”, Volume 2 London: W. Nicol BONADDIO FREDERICO (2010). Federio Garcia Lorca, The Poetics of SelfConsciousness, New York: Tamesis

DAS, SISIR KUMAR (1995). A History of Indian Literature 1911-1956, New Delhi: Sahitya Academy

DATTA, AMRESH (ed). (1988). Encyclopaedia of Indian Literatures: Vol II, New Delhi: Sahitya Academy

GANGULY, SHYAMA PRASAD (ed). (2006). Quixotic Encounters: Indian Response To The Knight From Spain, New Delhi: Shipra Publication

GANGULY, SHYAMA PRASAD (2005a). "Los Estudios Hispánicos en la India”, El español en el mundo:Anuario del Instituto Cervantes. 2005 $<$ https://cvc.cervantes.es/lengua/anuario/anuario_05/default.htm > accessed 10 September 2018

GANGULY, SHYAMA PRASAD (2004). "Don Quijote» bajo el cielo indio: traducción o transmigración". in Actas XV Congreso AIH (Vol. I). 2014 https://cvc.cervantes.es/literatura/aih/pdf/15/aih 15 1 $056 . p d f$ accessed 10 September 2018

GIBSON, IAN (2016). Lorca y el mundo gay, Barcelona: Edición B

KASBEKAR, ASHA (2006). Pop Culture India! Media, Arts, and Lifestyle, Santa Barbara, CA: ABC-CLIO

M. ATHIRA (2016). "Don Quixote in Kathakali Garb”, The Hindu. 23 June. https://www.thehindu.com/features/metroplus/Don-Quixote-in-Kathakaligarb/article14397096.ece accessed 12 September 2018

PANDEY, MANAGER (2013). Samvad-Parivamvad, New Delhi: Vani Prakashan

PEERS, DOUGLAS M. \& NANDINI GOOPTU (ed). (2012). India and the British Empire, UK: OUP

RODRIGO MATEU, AMPARO, (2016). "Interview with Govind Nihalani. Rukmavati Ki Haveli: Creating Emotional Landscapes" Fotocinema. No 13: July:321-329 
RAINA, M.L. (2013). "Refreshing Collection of an Elegiac Poet", The Tribune. 1 June. $<$ http://www.tribuneindia.com/2003/20030601/spectrum/book6.htm> accessed 12 September 2018

TEIGNMOUTH, LORD (1807). The Works of Sir William Jones, London: John Stockeden Piccadilly

SUBHAS YADAV is doing a $\mathrm{PhD}$ at the Centre for Comparative Literature, University of Hyderabad. He has been ERAMUS MUNDUS doctoral research scholar at the Universidad de Extremadura in Spain during 2017-2018. His academic interests are Hispanic literature, Comparative Literature, Cultural Studies, literary translation and Spanish teaching. 